\title{
SCIENCE, RELIGION AND ETHICS: THE RELIGIOUS ETHICAL BASIS OF INDIAN SCIENCE OF MEDICINE
}

\author{
Sreekumar Nellickappilly*
}

\begin{abstract}
It is often said that in Ayurveda, the Indian science of medicine, the scientific concerns are muddled up with religious and metaphysical convictions. This paper reies to show how while retaining the experiential route of science intact, Ayurveda shares certain imporant concerns with religion and philosophy in India. It affirms that this ultimately has helped Ayurveda successfully avoiding the problems associated with multiple ontologies--owing to a separation of science from values. Thsi paper will examine some important religious assumptions that play vital role in the conception and practice of the science of Ayurveda and how such approaches contributed in developing and integraing a strong code of medical ethics into the practice of medicine. The first section of the paper will bring out the experiential route of Ayurveda. The second section examines the concepts of disease and health/wellbeing in Ayurveda, in order to bring tout the ethical outlook ingrained in it. The thirs section will analyse some fundamental postulates fo Indian ethics and attempts to show that with the Vedic conception of Rita-cosmic moral order-Ayurveda uniquely defines itself as a way of physical, mental and ethical living, which aims at a very comprehensive notion of wellbeing.
\end{abstract}

Key words: Ayurveda, science, Indian medicine, Indian ethics

\section{CIENCIA, RELIGIÓN Y ÉTICA: LOS FUNDAMENTOS ÉTICOS RELIGIOSOS DE LA CIENCIA MÉDICA INDIA}

Resumen: Se dice a menudo que en Ayurveda, en la ciencia de la medicina India, se encuentran entremezcladas las preocupaciones científicas con convicciones religiosas y metafísicas. Este artículo trata de mostrar que, manteniendo intacta la ruta experimental de la ciencia, Ayurveda comparte ciertas preocupaciones importantes de la religión y la filosofía en la India. Afirma que esto definitivamente ha ayudado a Ayurveda a evitar con éxito problemas asociados con ontologías múltiples, debido a la separación de la ciencia con los valores. Examina algunos presupuestos religiosos importantes que juegan un papel vital en la concepción y práctica de la ciencia de Ayurveda y cómo tales aproximaciones contribuyeron a desarrollar e integrar un fuerte código de ética médica en la práctica de la medicina. La primera sección del artículo presenta la ruta experiencial de Ayurveda. La segunda, los conceptos de enfermedad y salud/bienestar en Ayurveda para extraer los aspectos éticos integrados. La tercera analiza algunos postulados fundamentales de la ética India y trata de mostrar que, con la concepción Védica de Rita -orden moral cósmico-, Ayurveda se define de forma única como un modo de vida físico, mental y ético, que apunta a una noción comprensiva del bienestar.

Palabras clave: Ayurveda, ciencia, medicina India, ética India

\section{CIÊNCIA, RELIGIÃO E ÉTICA: OS FUNDAMENTOS ÉTICOS RELIGIOSOS DA CIÊNCIA MÉDICA INDIANA}

Resumo: Afirma-se com frequência que, na Ayurveda, a ciência da medicina Indiana, encontram-se mescladas as preocupaçóes científicas com convicçóes religiosas e metafísicas. Este artigo objetiva mostrar que, mantendo intacto o caminho experimental da ciência, Ayurveda compartilha certas preocupaçôes importantes da religião e da filosofia na Índia. Afirma que isso definitivamente tem ajudado a Ayurveda a evitar problemas associados com as ontologias múltiplas - separando a ciência dos valores. Examina alguns pressupostos religiosos importantes que julgam ter papel vital na concepção e prática da ciência de Ayurveda e, como tal, aproximaçôes que contribuem para o desenvolvimento e a forte integração do código de ética médica na prática da medicina. A primeira parte deste artigo apresenta a rota experiencial de Ayurveda. A segunda, as concepçóes de enfermidade e saúde/bem-estar na Ayurveda para, então, identificar os aspectos éticos integrados. A terceira analisa alguns postulados fundamentais da ética Indiana e mostra que, com a concepçáo Védica de Rita-ordem moral cósmica-, Ayurveda se define de forma única como um modo de vida físico, mental e ético, apontando uma noçáo compreensiva de bem-estar.

Palavras-chave: Ayurveda, ciência, medicina Indiana, ética Indiana

\footnotetext{
* Assistant Professor (Philosophy). Dept. of Humanities and Social Sciences, IIT Madras, India
}

Correspondence: srkmenon@yahoo.com 


\section{Introduction}

Ayurveda, the Indian science of medicine, probably had its origin in the healing practices of the Indusvalley people of the Harappan civilization (2700-1700 B.C.E). Like many other ancient civilizations of Egypt and Mesopotamia, the healing system of this culture was also inextricably connected with the culture's religious beliefs and practices and probably even on magic(1). There are archeological evidences that indicate the prevalence of surgical practices in this preAryan civilization(2). Later with the establishment of the Vedic civilization, the pre-Aryan practices were integrated into a more comprehensive system of medicine. Meera Roy(2) observes that, while pre-Aryan elements led to the development of certain medical practices in Ayurveda, Indo-Aryan medical elements facilitated the growth of certain concepts and theories. The adoption of hygienic rules and regulations as part of medical practice, application of vapour bath in medical treatment and utilization of animal and material substances in medical prescriptions are some of the instances of borrowing by Ayurveda from the Indus-Valley culture. According to her, the Indo-Aryan medical elements facilitated the growth of concepts and theories that describe the cosmo-physiological speculations about the three basic constituents of living organisms (vata or wind, piitta or bile and kapha or phlegm), ideas about the aetiology of diseases and belief in the association of medical treatment with god-physicians.

The Vedas, originally composed between $1500 \mathrm{BC}$ to $600 \mathrm{BC}$, contain references to an advanced science of medicine. The Rig Veda and the Atharva Veda, the earliest and the latest among them -contain several references to this science. The Rig-Veda contains a prayer dedicated to the Aswinies, the twin divine physicians of Indian mythology, seeking protection from diseases, and it specifically refers to the notion of tridadhu(3). The concept of dhatu (tissue) is one among the three most important clusters of ideas in the Ayurvedic tradition, the doctrine of tri-doshas (three humours) and mala (waste products) being the other two(4). The ancient Indians have developed this science, incorporating their insights and knowledge about the animal kingdom, chemistry and other scientific pursuits with their peculiar mythological convictions, spiritual assumptions and religious practices(2).

Historically locating the foundations of Ayurveda in the (religious) healing practices of the Indus-Valley people and in the Vedic scriptures suggest how religious and mythological concerns were integrated with scientific pursuits. On the one hand, the scriptures deal not only with scientific pursuits, but also with moral prescriptions, magic, ritualistic practices and many other intellectual, religious and social concerns. The word Veda literally means knowledge, and here it is employed in the broadest possible sense to include all the wisdom and insights of the ancient Indians concerning life and the cosmos. To separate the scientific endeavors in order to appreciate their peculiar features is a difficult task. On the other hand, all the sciences carry this Vedic legacy and consider several assumptions and convictions that sound religious and spiritual in nature as having an important place in their respective pursuits.

To understand Ayurveda as a science, we may have to appreciate three factors. First, the experiential basis of this science, which is to be found in the fundamental epistemological position adopted by Ayurveda, that has been developed by the Indian logicians and philosophers of science. There is a detailed analysis of the philosophical foundations of the "causal explanation" method adopted by sciences in order to acquire knowledge. Secondly, comes the theoretical presuppositions and fundamental concepts of Ayurveda. This can be referred to as the ontology of Ayurveda, as there are presuppositions about many theoretical entities and their mutual relationships. The basic cosmo-physiological assumption about the three basic constituents of living organisms, viz. vata, pitta and kapha, which is central to Ayurveda, is an example for this. Finally, the intimate and intrinsic ways in which a moral point of view is ingrained into such epistemological and ontological assumptions make Ayurveda, not just a science, but a way of physical, mental and spiritual living, which aims at the eradication of all kinds of sufferings including diseases. There is no epistemology which is independent of speculations about a spiritual self and moral life to be lived by the embodied self in this world. The conception of knowledge, therefore, is not confined to empirical scientific knowledge, but is extended to incorporate moral wisdom as well. The philosophy of life propagated by Ayurveda is complete only with a conception of life that comprehensively covers the physical, mental and the moral ways of living in a natural and social environment.

This paper attempts to bring out three things. The first section will show, how, in spite of its entanglement with 
religious and moral concerns, Ayurveda emphasizes an experiential route that keeps its status as a science intact. The second section will examine the ways in which Ayurveda as a science of curing diseases understands human life and its well-being. This section will explain the fundamental ethical outlook of Ayurveda which suggests that it is not just a science that addresses the psycho-somatic wellbeing of the individual, but also an ethical way of living that aims at elevating the individual to the highest potentials of his being. The third section attempts to expose the four fundamental postulates of Indian ethics-the belief in the fundamentality of suffering in our corporeal existence, belief in karma theory, belief in an eternal soul and the conviction about the highest spiritual emancipation in life. Through Karma theory, Ayurveda reiterates what almost all Indian philosophical traditions believe, that each one of us are responsible for our present life, which is characterized with a unique mixture of sufferings and enjoyments. We enjoy or suffer by virtue of the moral force of our own actions performed in the past, both in the present and previous lives. The belief in an eternal soul reaffirms this responsibility aspect and the idea of spiritual enlightenment establishes that ultimate freedom from sufferings comes only by the attainment of spiritual emancipation.

\section{Ayurveda as a Science}

The term Ayurveda is derived from the two words, ayus and veda: ayus means life and Veda means knowledge or science. The term ayus is derived from the root " $P$, which means "to go" which indicates the continuity of existence. Hence Ayurveda is the science that aids continuous existence(2). As a science it deals with animal and vegetable medicines and provides a detailed account of the chemical properties and medicinal value of hundreds of species of plants. This vast knowledge is the result of persistent careful observation and systematization carried out by generations of physicians in ancient India. Even when it occasionally slips into metaphysical and religious contemplations, the sciences in India, particularly Ayurveda, had maintained the experiential root that defines its status as a science intact.

But as a result of its entanglement with the religious outlook, Ayurveda firmly subscribes to the belief that it is of divine origin, originally departed by Lord Brahma, the creator God of Hindu mythology. It also believes in the karma theory, by which one's past karmas (actions) are responsible for one's present life and hence for one's state of health as well. Again, as mentioned above, in its conceptions of wellbeing, it doesn't stop with an idea of psycho-somatic wellbeing, but envisages an ideal of spiritual emancipation which is frequently referred to in the Indian religious and philosophical traditions as moksha or kaivalya. Occasionally this calls for a conception of eternal soul. Caraka, one of the ancient masters of Ayurveda and the author of Caraka-Sambita, a fundamental textbook, elaborately discusses the concept of soul along with the concepts of body and mind.

On the other hand, as a science Ayurveda strongly affirms that it is possible to overcome all kinds of sufferings with the right knowledge of things and the world. It locates its basis on an epistemology of sense experience. As Debiprasad Chattopadhyaya, one of the prominent philosophers of modern India notes, the only discipline that promises to be fully secular and contains clear potentials of the modern understanding of natural science is medicine(5). Ayurveda affirms the value of this experiential basis of their knowledge system as perennial. Chattopadhyaya, observes that, the theoretical achievements of ancient Indian sciences were ignored and often misunderstood mainly because they were strangely muddled with many features of the counter-ideology. But according to him, Ayurveda has already taken the momentous step from magicoreligious therapeutics (the pre-Vedic and Vedic origins) to rational therapeutics. He argues that the distinction between daiva-vyapasraya bhesaja (God-dependent medical practice) and yukti-vyapasraya bhesaja (reasondependent medical practice) is repeatedly drawn in the Caraka-Sambita, which makes clear that the rational therapeutics alone represent the technique of Ayurve$d a(5)$. To understand what is intrinsic to Indian science, we have to examine its epistemological presuppositions, which will reveal its experiential basis.

The inferential process followed by the ancient Indian epistemologists is at the center of the scientific methodological approach of Ayurveda. The Indians called it Anumana, which is a process of ascertaining, not by perception or direct observation but through the instrumentality or medium of a mark, that a thing possesses a certain character. It is based on the establishment of an invariable concomitance between the mark and the character inferred(6). This invariable 
concomitance is called Vyapti, which is ascertained by observation and experiments. Srinivasa Murti points out that the observation of agreement in presence (anvaya), as well as the agreement in absence (vyatireka) between two phenomena, with the non-observation of the contrary (Vyabhicharadarsanam) is the foundation of our knowledge of vyapti(6). The unconditionality of the concomitance needs to be established in order to ascertain vyapti. Since nature does not always supply us with positive and negative instances of the right kind of help to establish or reject theories, we may have to employ the method of indirect proof (tarka) to obtain the negative evidence. The method of indirect proof is employed to strengthen the universal proposition based on positive instances of uninterrupted agreement(7). Both the principles of causality as well as the uniformity of nature are established by means of repeated observations and vyapti based inferences. Srinivasa Murty observes that, this Indian method is a combined Formal-Material, Deductive-Inductive inference and hence is more comprehensive than Aristotle's or Mill's analysis of syllogism(6).

The employment of an observation method is repeatedly emphasized in ancient texts like the CarakaSambita. As M. S. Valiathan(8) points out, the method of observation was perennial in the development of Ayurveda. The sick animals and birds choosing to eat selected plants which they normally never consume had caught the attention of ancient observers who sought to apply similar remedies in human situations. He says that, Charaka even refers to the lore of shepherds and forest dwellers and though the Atharvan hymns are invocatory in nature, the science of medicine, when it is practiced was never confined to magic or priestly hocus-pocus, even in the Vedic age(8).

This enables the pursuit of knowledge of the scientist a rational-logical process, which is different from many other forms of enquiries. But in the Indian context, such scientific pursuits were never essentially separated from other forms of enquiries. The substantive reason that unites all human concerns is never fragmented in India, as it happened in Europe with the advent of modernity(9). In other words, the cognitive is not separated from the conative and the aesthetic and the concept of "wellbeing" in Ayurveda is intrinsically related to the notion of life -and its fundamental objectives and means- where the disentanglement of the intellectual from the ethical and material from the spiritual are impossible. To understand this we have to examine how Ayurveda conceives diseases and what ultimately is its conception of wellbeing. This will reveal the relevance of the fundamental ethical postulates mentioned above in the very conception of Ayurveda as a science of healing.

\section{Disease and Wellbeing in Ayurveda}

Ayurveda, as mentioned above is the science that deals with the sustenance or continuation of life. Hence one important concern of Ayurveda is the removal of rogas or diseases. It adopts the Sankhya-Vedanta cosmology -both are schools of philosophy that belong to the orthodox Hindu tradition-in order to explain the nature of the physical world and also the human soul which plays an important role in the process. According to the Sankhya school, the whole of reality consists of two principles: the partless and qualityless souls (Purusha) and nature or the root principle of matter (Prakriti). To explain the human individual, Sankhya employs both these principles. The principle of matter is constituted of infinite gunas or qualities, which are further classified under three broad classes based on their predominant characteristic feature: sattva (intelligence-stuff), rajas (energy-stuff) and tamas (mass-stuff). They are substantive entities or subtle substances and not abstract entities(10). The Sankhyans affirm that, the principle of matter in its "natural condition" exhibits an equilibrium of these three gunas, which is disturbed due to the arrival of Purusha, the principle of consciousness. The evolution of the embodied self -the individualhappens as the result of such an apparent union of the soul and matter.

The most significant aspect about Ayurveda lies in its conception of the individual whose healthy life is its prime concern. Ayurveda here brings together material, social and spiritual dimensions of life. A human being has twelve components: the three dosas or humors, the three gunas or constituents of nature, the five senses and atman or soul(11). Hence the conception of wellbeing too refers to the wellbeing of the body, mind and soul. There is a concept of fundamental objectives of life for individuals, widely subscribed to by all systems of thought and schools of philosophy in ancient India. This is known as the doctrine of four purusharthas (human goals). They are: dharma (righteousness or duty), artha (wealth), kama (desire for pleasure) and moksha (spiritual emancipation). The first three are for the 
body and mind and the last one, which is treated by the spiritual traditions as the most important one, consists in the realization of the soul. Astangasamgraha(12) one of the very important texts of Ayurveda composed by Vaghbata, says:

Dharmarthakamamokshanam vighnakaribhiramayai Nareshu peedyamanushe puraskruthya punurvasum DhanvanthiriBharadwajaNimiKasyapah Maharshayo mahatmanasthata Lambayanadayah Sakratumupajagmu saranyamamareswaram

(When humanity was troubled by those diseases which prevent them pursuing dharma, artha, kama and moksha, the great sages like Dhanvanthiri, Bharadwaja, Nimi, Kasyapa and Lambayana have approached Indra the King of Gods.)

In the conception of the living organism (human body in particular), Ayurveda conceives it as constituting of three doshas, and the 'natural condition' of the body is said to be a state of equilibrium of these three doshas. When this natural equilibrium is disturbed -due to several external and internal reasons- we encounter diseases. Restoration of the natural harmony of the humours in the body will restore the natural condition of the body, which can be understood as Arogya, (health or wellbeing), a state of existence which we will become aware of only when we lack this harmony. A human being in Ayurveda is a union of matter and soul, where the mind plays an important role, as it is not strictly separated from matter or body and is constituted of the three gunas of the root material nature. Hence the mind is not different from the body and the treatment for the body aims at treating the mind as well.

Diseases and their causes are understood in terms of three aspects: functional, physical and moral. Functionally, disease is caused by a state called dhadu vaishamya, or imbalance of the three dhadus or doshas (humours). The aggravation of a disease, therefore, depends on the extent to which the three humours are deranged(2). The properties of the substances used as drugs aid the curing process by rectifying the deranged humours. With regard to the causes the imbalance of doshas, Ayurveda adopts a psycho-somatic approach, which has very strong moral implications. Apart from the normal physical causes like climatic conditions, the desires for material pleasure and passions are considered as causing and aggravating diseases. In other words, Ayurveda recognizes certain moral factors too as the causes of diseases. Astangasamgraha(12), begins with a prayer to the Eka vaidya, or the unique absolute physician, whose grace is essential for the curing of the diseases. It says:

\section{Ragadiroga sahajassamoola Yenasu sarve jagathopyapaastha Thamekavaidyam sirasa namami Vaidyagamajnamcha pitamahadin}

(With whose grace, those diseases which are the results of the desires and passions and which are natural to the body are cured, I salute that unique absolute physician. Salutations to all those grand predecessors who imparted the science of medicine.)

It recognizes the relationship many diseases have with the ragas, or passions and desires. They are raga (clinging to sensual -physical and mental- pleasure), dvesha (aversion to physical and mental pains), lobha (desire to possess), moha (delusion), mada (arrogance) and matsaryam (hatred). These are the root causes of diseases. With the administering of drugs one can get rid of the bodily manifestation of diseases, but the root causes may remain dormant. This can be removed only by adopting the right and balanced mental attitude towards life. One has to overcome the extremes of passions and desires.

According to the Indian metaphysical (religious and philosophical as well) traditions, the root cause of all sufferings is ignorance about the real nature of self. Vaghbata, the author of Astangasamgraha and Astangahridaya, was a Buddhist and hence the reference to Apurva Vaidya (unique physician) aims at Lord Buddha, whose spiritual teachings urge man to overcome all sufferings by the removal of desires which are caused by ignorance. The Sankhya system of philosophy proclaims that the ultimate form of ignorance is the fundamental confusion between Prakriti and Purusha or matter and soul. Passions and desires reside in the body which is material and hence is constituted of the gunas, while the Purusha which is pure spirit and pure consciousness is absolutely devoid of all passions and changes. Due to ignorance the pure soul is wrongly identified with matter and hence appears to be subjected to the different kinds of sufferings. As a result, the individual acts and approaches the world with passions and desires, which lead to various forms of physical as well as mental imbalances that ultimately cause diseases. Only the spiritual knowledge bestowed by the unique physician can free us from this, as ordinary physicians can only remove -that too only 
temporarily- the physical manifestations and not the root cause of diseases. To eradicate the root cause -the ragas - one needs to elevate spiritually, by realizing the fundamental unreality of all pleasures and pains and by rising beyond all such dichotomies.

Practically, the process of treatment starts with the assumption that, disease is the result of the imbalance of dosas. Hence to attain health, one needs to regain the balance, by means of rearranging life to facilitate it. The physical and chemical properties of the drugs aid the patient in regaining the balance in the body which is called samyavastha. But even after the bodily manifestations of the imbalance are overcome, the tendencies remain dormant, mainly as the result of past actions or karmas (we shall discuss this aspect in the next section). Moreover, the dhatu samya or the state of health is a psycho-somatic state and so long as the mind clings to the passions and desires (ragas), wellbeing in the real sense is unachievable. Hence the overcoming of passions plays the most important role in the positive rearrangement of life and subsequently of the deranged dosas. The seat of all these passions is the mind (citta) (12), which is a subtle form of the body. Hence the control and regulation of the mind -and the passions- is vital in the comprehensive form of treatment suggested by Ayurveda. Astangasamgraha(12) adds:

\section{Trishnadirgamasadwikalpasirasam}

Pradveshachanchalphanam

Kamakrodhavisham vitarkadarsanam

\section{Ragaprachandekshanam}

Mohasyam swasarirakodrasayam

Chittoragam darunam

Prajnamanthrabalena yasmitavan

Buddhaya tasmai namah.

(I salute the Buddha, with whose discriminatory wisdom alone one can conquer the mind which is a serpent, whose length is proportional to its desires, whose false conception is its forehead, whose hatred is its moving hood, whose doubts are its teeth, whose passions are its terrific eyes, whose delusion is its face and who resides in its body).

This control of the mind, according to the Yoga and other systems of Indian philosophy, leads to the state of vira or Vairagya, which indicates detachment from the sensual world and its enjoyments and sufferings. The comprehensive mode of treatment suggested in
Ayurveda envisages attaining this. Hence it has the following steps as integral parts of treatment.

1. Proper food: Ayurveda considers even food as a medicine. Traditional Ayurveda thus prescribes an ideal diet which includes those items which are appropriate to the climatic conditions and those which do not disturb the dosa equilibrium in the body. There are three types of food: that which is of the nature of satva, of rajas and of tamas. The gross portion of food evolves into mala (excreta or waste product), the subtle portion to manas or mind and the portion in between them to dhadus and the gross body. Hence the power of food to influence the body and mind makes it very important in the scheme of Ayurvedic treatment. In order to conquer the ragas (passions), which are the root causes of diseases, one needs to purify the mind with the purity of food. Rajas is responsible for all mental disturbances and the right kind of food aids purifying the mind from this excess(13).

2. The different types drugs, which are expected to aid the body achieving equilibrium.

3. Achieving a balanced mental state, devoid of passions and desires for sensual pleasure. One should keep away from enjoying pleasures which are prohibited, asserts Astangasamraha(12).

4. The right attitude towards others as well as to the environment. This is articulated in the concept of dharma or duty by the Indian tradition. This dharma is treated as the principle of life and Astangasamraha(12) affirms: "All beings desire for comforts and act for them. But this is unachievable without observing dharma (duty). One who aspires for the comfort of health ought to observe dharma". This ultimately calls for the cultivation of vairagya, or detachment from the world of sensual pleasure.

Ayurveda does not distinguish between these different stages or kinds of treatments: by medicines, food, mind control, moral attitude. Instead, it makes all these different elements integrated into a way of life. We shall now see what constitutes the basis of the ethical approach of Ayurveda. In order to understand this we now analyse the fundamental postulates of Indian ethical thought and examine their relevance in Ayurveda. 


\section{Suffering, Karma, Soul, and Emancipation: Four Fundamental postulates of an Ethical Theory}

There are four fundamental postulates of Indian ethics: the universality of suffering of worldly existence, the belief in karma theory or the law of moral causation, (sum of person's actions in one of his successive states of existence, viewed as deciding his fate for the next), the eternity of soul, which justifies moral accountability and the possibility of spiritual emancipation (and the overcoming of all sufferings) by the removal of ignorance by means of right knowledge.

The doctrine of the universality of suffering says that the existence of the embodied self is essentially characterized by sufferings. The term samsara is used to characterize the life in the world of the embodied self. Samsara is the beginningless series of births and deaths and the bondage to embodies life in the spatiotemporal world. It also indicates the imprisonment of the pure soul in an impure body, due to ignorance(14). All pleasures and pains are momentary. We have a natural inclination to seek pleasure and avoid pain, which is termed as kama. This is a futile exercise, as corporeal existence is characterized by both pleasures and pains and to avoid one and to search for the other is not possible. Buddhism develops its four great principles -the Arya Satyas- in association with this idea. It equates the worldly existence with $d h u k a$ or sorrows/sufferings. The second one affirms that since every effect has a cause, dhuka too has a cause and that is ignorance. The third one states that it is possible to overcome suffering and fourth one prescribes the means by which this is achieved.

According to the philosophical traditions, there are three types of sufferings: Adhyatmika, the sufferings of one's own body and mind; Adi-bhautika, the suffering due to other living beings; and Adi-daivika, the sufferings due to supernatural agencies(14). Ayurveda conceives disease as a $d h u k a$, which can be overcome through the right kind of medicines and the right form of living. But the effectiveness of treatment depends on physical, mental and supernatural causes of the disease. Many of these causes can be eradicated through the administering of right medicines, adoption of right diet and the right (following dharma) way of living with perfect control over passions. But one's own past karmas (sum total of past actions and their moral force) will still have some impacts on one's life, which will result in sufferings and enjoyments in the present and future lives. These karmic forces influence in the form of inner dispositions (vasanas) that manifest in the form of various tendencies that prompt one to act. The control over mind and the cultivation of detachment (vairagya) are suggested in order to overcome these impacts. Such a conception of karma and its impacts presuppose a notion of soul, which is eternal and which transmigrates. This concept implies moral accountability. The individual is thus accountable for his/her acts and he/she alone can overcome the impact of his/her karmic forces by conquering his/her mind which is the seat of passions and tendencies through which the karmic forces are activated. The fourth postulate is the most important one, as it is projected by many spiritual traditions as the final goal. It consists in transcending all passions and desires and achieving a state of existence where one is unaffected by all those desirable as well as undesirable changes the rest of the world undergoes.

The role of Ayurveda as a science that aids curing diseases is vital here, as in a disease affected state, human begins cannot pursue their fundamental aspirations which include, dharma, artha, kama and moksha. Hence the fundamental objective of the science of Ayurveda is to facilitate the pursuit of purusharthas, and since spiritual emancipation (moksha) is the highest goal among them, it is the fundamental objective of Ayurveda as well.

These are the postulates of morality, which are foundational to the conception of science as well. While the spiritual traditions conceive the notion of sufferings exclusively from the light of the highest spiritual goal, Ayurveda understands it by equating it with various psycho-somatic diseases. The solution to the problem of sufferings is sought in the fulfillment of the spiritual life by religion, while Ayurveda focuses on the more immediate physical and psychic causes for diseases and supplements the pursuit of the highest ideal with a removal of the impediments to its pursuit in the form of diseases. The science based on observation and experiments does not contradict the religious pursuits, rather complements it by contributing to improving the conditions that facilities them. What enables this in the Indian context is the entanglement of the three kinds of words -and subsequently three forms of discourses- the word of the question (philosophy and sicence), the word 
of the legend (poetry) and the word of the reconciliation and the promise (religion). As Hans George Gadamer observes, only in the history of the western civilization and culture that these three forms of discourses and the word have been distinguished and developed through continuous interchange of ideas with one another(15). Such a disentanglement is absent in the Indian civilization -both historically as well as conceptually-as all the intellectual and other human concerns -sciences, arts, religion, social sciences, philosophy- share a common functional framework. This framework decided the fundamental assumptions, objectives and operational procedure of each of these endeavours and determined their ontological presuppositions and epistemological presumptions.

This strong unified ethical framework which legitimizes the vey sanctity of the various pursuits is a Vedic legacy. The Vedic outlook is dominated by a conception of cosmic moral order, which it is technically designated as Rita. According to this, there is a cosmic moral order that pervades and prevails the universe, which refers to and accounts for both the natural cosmic order as well as moral behaviour of the individuals in the society. As Kireet Joshi(16) observes:

...there is, at the summit of consciousness, a power of action which arranges forces and activities of the universe by an automatic harmony of relationships, movements and results. The right law of this automatic harmony is Rita. The Rita itself is founded in the truth of the Reality and of the universe, (satyam), and its field of action is the totality which is the infinite vast (brihat).

The all-persaviness of Rita is further reiterated by a conception of cosmic reality. The hymn 10.129 of the Rig Veda, which is also known as the 'hymn of creation' metaphorically describes how the whole existing universe has come about. It says that an absolute being (Tat Ekam), which is identical to Satya or Truth, existed eternally. With this the Rig Veda affirms the unity of all existence, living and non living. "From Fervour kindled to its height Eternal Law (Rta) and Truth (Satyam) were born:

Thence was the Night produced, and thence the billowy flood of sea arose", proclaims the Rig Veda(3). The unity thesis is affirmed in many ways. The hymn 8.58.2 of the Rig Veda(3) says:
Eka evagnir bahudha samiddha

Ekah suryo visvam anu prabhutah

Ekaivosah sarvam idam vibhaty

Ekam vaidam vi bahuva sarvam

(One fire burns in many ways; one sun illumines the world; one dawn dispels the darkness of night; All that exists is One and It has taken all these various forms.)

These Rig Vedic assumptions remain as the core of the Vedic cosmology, which exerted significant influence in the formation of theories in religion, science, ethics and philosophy. The unity of Truth and Law, and subsequently the fundamental unity of all being, is manifested in Rita, both at the micro as well as at the macro levels. The fundamentality of Rita is repeatedly reiterated as it is conceived as the law of truth, and the sole law to which the individual and the collectivity are called upon to give their ultimate allegiance(17). All human endeavours are therefore, in a sense, attempts to cope up with this law of truth and all enquiries -scientific, moral, aesthetic, political, social etc.- aim at understanding this law from different perspectives.

The ancient Indians have developed a concept of dharma, in the light of these insights. Dharma is equated with Rita. It is a regulatory principle, which guides the lives of all people. Since it is a principle of life, it has applications in all human endeavours viz, political, economic, social, scientific, artistic, religious and spiritual. These different spheres, though are functionally divided, are fundamentally united in terms of the all pervading order of Rita. Ayurveda's conception of the being of man -as constituted of three dosas, three gunas, the senses and the soul- reflect this cosmic order in the microcosm, as it envisages a state of balance between contradicting forces. The state of dhatu samya (equilibrium of the dosas) and subsequently the conception of health or wellbeing are understood in terms of such a conception of order and harmonious existence, which is understood as the "natural condition" of the body. The natural condition therefore, reflects the cosmic -natural and moral- harmony in the microcosm.

The influence of this Vedic legacy which consists in the idea that all that exist -living and non living-are regulated by Rita, and hence they reflect the cosmic harmony in their natural condition, exerts a strong moral force on all human actions. It makes the realiza- 
tion of this harmony, not only important in the different spheres of human action, but also the ultimate human aspiration. This moral force, as mentioned earlier, encompasses the domains of 'is, can and ought', and is understood as dharma. Ayurveda aims at human wellbeing, which as discussed above physical, mental an spiritual dimensions. It therefore, prescribes a life which follows dharma, in words and deeds. The proper administering of medicines and proper diet need to be supplemented by the proper conduct. The ultimate aim of Ayurveda, is not freedom from physical pains, but a liberation from all sufferings.

\section{References}

1. Zysk Kenneth G. Asceticism and healing in Ancient India. Corrected edition. Delhi: Motilal and Benarsidas; 1998.

2. Roy Meera. Ayurveda. In: Ray Priyadaranjan, Sen SN, (editors). The Cultural Heritage of India, Vol. VI: Science and Technology. $2^{\text {nd }}$ ed. Kolkata: The Ramakrishna Mission Institute of Culture; 1986: 152-176.

3. Griffith RTH, (translator). The Rig Veda (Book in the Internet). 1.0 edition Evinity Publishing Inc; 2009. Available from: http://www.sacred-texts.com/hin/rigveda/

4. Wujastyk D. The Roots of Ayurveda. $2^{\text {nd }}$ edition. New Delhi: Penguin Books; 2001.

5. Chattopadhyaya D. Science and Society in Ancient India. Calcutta: Research India Publications; 1977.

6. Murti Srinivasa G. The Science and the Art of Indian Medicine. $1^{\text {st }}$ ed. Adyar: The Theosophical Publishing House; 1986.

7. Radhakrishnan S. Indian Philosophy, Vol.2. New Delhi: Oxford University Press; 1989.

8. Valiathan MS. The Legacy of Charaka. Hyderabad: Orient Longman Private Limited; 2003.

9. Habermas J. Modernity: An Unfinished Project. In: Passerin D'Entreves M, Benhabib S, (editors). Habermas and the Unfinished Project of Modernity. Cambridge: Polity press; 1996: 38-55.

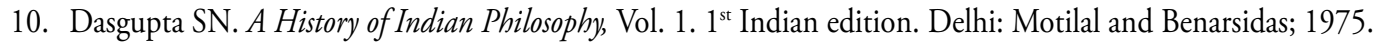

11. Sharma PV. Essentials of Ayurveda. Text and Translation of Sodasangahrdaya. Delhi: Motilal and Benarsidas; 1998.

12. Thirumulpad K. Raghavan. Astangasamgraha: Prakashika Interpretation. (in Malayalam). Chalakudy: Prakashika; 2006.

13. Thirumulpad K. Raghavan. Bhaishajyadarsanam. (in Malayalam). Thiruvananthapuram: Kerala Bhasha Institute; 2002.

14. Sinha J. A History of Indian Philosophy, Vol.1. Calcutta: Central Book Agency; 1952.

15. Gadamer H-G. Praise of Theory. New Haven: Yale University Press; 1998.

16. Joshi K. The Veda and Indian Culture. Delhi: Motilal and Benarsidas; 1991.

17. Ganguli KM, (translator). Mahabharata. Available from: http://www.mahabharataonline.com/translation/index.php

Recibido: 2 de marzo de 2010

Aceptado: 28 de marzo de 2010 